\title{
Nesting behaviour and larval biology of Prionyx fervens (Linnaeus) (Hymenoptera, Sphecidae) from Brazil
}

\author{
Sandor C. Buys \\ Departamento de Entomologia, Museu Nacional, Universidade Federal do Rio de Janeiro. Quinta da Boa Vista, São \\ Cristóvão, 20940-040 Rio de Janeiro, Rio de Janeiro, Brasil. E-mail: sbuys@biologia.ufrj.br
}

\begin{abstract}
The nesting behaviour of Prionyx fervens (Linnaeus, 1758) is described, based on one nesting female observed in a coastal environment from southeastern Brazil. One prey bearing a wasp's egg was created in laboratorial conditions and aspects of the larval behaviour and development are described. Schistocerca cancellata (Serville, 1838) (Caelifera, Acrididae) was found as prey.
\end{abstract}

KEY WORDS. Immature; reproduction; Sphecini; wasp.

RESUMO. Comportamento de nidificação de Prionyx fervens (Linnaeus) (Hymenoptera, Sphecidae) no Brasil. O comportamento de nidificação de Prionyx fervens (Linnaeus, 1758) é descrito, baseado em uma fêmea nidificante observada em um ambiente costeiro do sudeste do Brasil. Uma presa portando ovo da vespa foi criada em condições de laboratório e aspectos do comportamento e do desenvolvimento da larva são descritos. Schistocerca cancellata (Serville, 1838) (Caelifera, Acrididae) foi encontrada como presa.

PALAVRAS-CHAVE. Imaturo; reprodução; Sphecini; vespa.

Prionyx Linden, 1827 is a genus of solitary ground-nesting wasps that hunt on grasshoppers. This genus has almost 60 species widely distributed around the world (BOHART \& MENKE 1976). The biology of only a few species of Prionyx has been studied (e.g. Hartman 1905, Rau \& Rau 1918, Janvier 1928, Evans 1958, Genise 1980, 1981, Grissel 1981, Evans et al. 1982, Steiner 1981, 1982). Prionyx fervens (Linnaeus, 1758) occurs from Argentina to southern USA (WiLLInk 1951, Bohart \& Menke 1976 , Amarante 2002). Some notes have been published on biology of this species. Willink (1951) prospected the early literature on biology of Prionyx and Evans (1958) comprehensively reviewed the biology of the genus and related inedital observations made by Ernest C. Bay on P. fervens from Mexico. BONDAR (1915) made a short note on behaviour of this species based on observation carried out in Brazil, which is not mentioned on the revisions by WILLINK (1951) and Evans (1958). Herein more detailed notes on biology and larval development of $P$. fervens are presented.

The study was based on one nesting female observed in the Parque Estadual de Jurubatiba (Municipality of Macaé, Rio de Janeiro State, southeastern Brazil; September 10, 2002), in the margins of a dirt road near to the beach.

\section{RESULTS}

The female was seen at about 11:00, resting on a small shrub near her prey, an adult Schistocerca cancellata (Serville, 1838) (Caelifera: Acrididae: Cyrtacanthacridinae). The paraly- sed prey had been stored on a branch of the shrub, $11 \mathrm{~cm}$ from the soil. Then, the wasp flied off and remained for about two hours in searching for a site to dig her nest. In such a period she backed only one time to the prey storing-place to inspect her. During the selection of the nesting site, the female did not distance more than $15 \mathrm{~m}$ from the prey. The female selected the nesting site walking on the ground and antennating the substratum. She tried to cut with the mandibles the soil from the midst of the road in several points, but did not effectively excavate, apparently because the soil was very hardly compacted. Every point the female tasted during the nesting site selection was exposed to the sun and without litter. The female started to dig two burrows in the soil less compacted of the margin of the road (one with $32 \mathrm{~mm}$ deep and $17 \mathrm{~mm}$ in diameter), but abandoned them. In one of such occasion, she threw backward beneath her body with a synchronic movement of the forelegs a small amount of sand to the interior of the abandoned burrow. The nest was excavated in the margin of the road in a point with substratum composed of course sand, fragmented seashells, and clay.

In order to dig the burrows, the female cuts the soil with the mandibles, holds a lump of earth between the forelegs and oral portion of the head, walks backward, and throws the earth backward beneath the body, with a quick movement of the head and forelegs. The earth is thrown a few millimetres beyond her body. When she cuts the soil, emits an easily audible buzzing sound. Often, the wasp interrupted for some seconds 
the excavation and rested on plants nearby, about $15-25 \mathrm{~cm}$ from the soil, and apparently 'looked vigilantly' at several distinct directions. During the pauses, she moved more rapidly than in other phases of the nesting cycle and she easily threatened. Always before releasing the excavation, she emitted a characteristic short buzzing sound. The pauses were more frequent in the early of the nest construction. Some times during the nest excavation, I threatened the wasp approximating a small object, and she always reacted with a very characteristic movement of alternately sustaining her body on the legs of the distinct sides of the body and quickly inflect them.

The nest was a curved tunnel, strongly oblique in relation to the ground, with about $13 \mathrm{~cm}$ in total length and $2 \mathrm{~cm}$ in diameter. The entrance was a few broader, with about 2.5 $\mathrm{cm}$ in diameter. The overall time spent in the excavation of the nest was about 40 minutes. The nest was $14 \mathrm{~m}$ distant from the prey-storing place. Soon after the nest being ready, the female flied in searching of the prey. She grasped the base of her antennas with the mandibles, straddled her body, and walked toward the nest entrance, dragging her on the ground. The wings of the wasp strongly vibrated whereas she was carrying the prey. This behaviour apparently helps in driving the wasp forward carrying the prey, which is very heavier than her own body. In a place without plants, litter or others obstacles, the wasp moved the wings with more velocity, and could walk very more quickly. However, in any moment she raised the prey up from the ground. The female let the prey in a second storing place, on the ground, $85 \mathrm{~cm}$ distant from the nest, in an exposed place, with the dorsum side up. She spent about two minutes to transport the prey from the first storing place to the second one. After that, the female dug during five minutes, inspected the prey, and dug for more three minutes. Then, she brought the prey to the nest entrance and entered the nest walking backward. She partially came out from the nest, walking forward, grasped the base of the prey antennas, and pulled her to the nest interior, walking backward. She oviposited and came from the nest, walking forward. Soon after that, she started to close the nest using the earth accumulated from the nest excavation. In order to close the nest she throws to the nest interior lumps of earth backward beneath her body with the forelegs. Then, she enters the nest and compacts the earth with the mandibles. In this moment her entire body vibrates and she emits a buzzing sound, which is longer and very distinct from those previously observed.

The prey was deposited inside the nest, with a lateral portion of the body up and the head turned to the bottom the cell. The egg was attached to the body of the prey in the junction of one foreleg with the thorax.

\section{Development and behaviour of the larva in laboratorial conditions}

10/09 - the egg was sausage-shaped, but strongly curved, and intense yellow in colour. The grasshopper was able to move the mouthparts and often he vigorously extended the hindlegs, as he does when he jumps.

$11 / 09$ - the egg gradually gained a brownish coloration. The prey remained able to vigorously move the hindlegs.

$12 / 09$ - the egg hatched and the larva inserted the anterior part of her body in the junction between the leg and the body of the prey, where the egg had been attached. The prey was alive, but was unable to vigorously move the hindlegs.

13/09 - the larva graded from light green to brown. The prey died, probably in the night.

14/09 - during the major part of the day, the larva remained partially inside the prey body, as in the early development, and did not perceptibly move her body. At about 22:00 h, the larva started to consume the prey externally.

15/09 - the larva gradually gained an intense yellow coloration. At about 10:00 h, the larva stopped to feed, remaining only the hard parts of the exoskeleton of the prey. The body of the larva was sharply divided in anterior portion, including the thorax and first abdominal segment, and posterior portion, including the other abdominal segments. The former was somewhat cylindrical, reddish in colour, without grains of uric acid visible under the integument, and with active movements. The latter was flattened ventrally and rounded dorsally, very broader, predominantly yellowish in colour, rich in grains of uric acid visible under the integument, and with scarce movements. The larva was put in a glass tube and, soon after, started to spin her silken cocoon. At about 17:00 h, the cocoon was fusiform, with mamiliform projections in the extremities. She continued up to the night coating internally the cocoon with a brownish substance that she excreted from the mouth. The cocoon had two walls of silk embedded in a brown matrix.

\section{DISCUSSION}

In general lines, the behavioural patterns of $P$. fervens seem to be not significantly different from those observed in others species of the genus. The behaviour of species of Prionyx, with some exceptions, has showed closely similar (Evans 1958). However, two behavioural patterns herein reported in $P$. fervens, apparently related to defence against natural enemies, were not previously reported in others species of the genus: (1) the stereotyped movements in reaction against an incitement and (2) the pauses in the nest excavation, in which the wasp apparently is vigilant. Degrees of intra- and interspecific tolerance and territoriality among Sphecidae are few understood, in part because studies on fixed action patterns on these wasps are usually restricted to those concerning the construction of the nest and prey manipulation. Defensive or agonistic behavioural patterns are rarely emphasised.

The most species of Prionyx hunts the prey before digging the nest (Evans 1958, Bohart \& Menke 1976). The observations related by Evans (1958) on P. fervens, as well as those herein related, agree with this general pattern. WiLlink (1951) com- 
mented that Conil found $P$. fervens digging the nest before hunting the prey, observation that was questioned by Evans (1958). It is quite probable that the note by ConiL is fruit of a misinterpretation or a fortuitous event as one I observed during a study on biology of Prionyx thomae (Fabricius, 1775) in southeastern Brazil (Sandor Buys in preparation). I have observed a dozen of times females of this species preying before preparing the nest. These females put the prey in a storing-place before dig the nest similarly to $P$. fervens. But in one occasion, one female was not able in finding the prey in the storing-place, apparently because some predator removed this prey, then she hunted another prey and stores it in the same before constructed nest.

BONDAR (1915) reported the following species of grasshoppers as prey of P. fervens: Schistocerca flavofasciata (Geer, 1773), S. paranensis (Burmeister, 1861), and Xyphocera discoides (Burmeister, 1861).

The development and behaviour of the larva of $P$. fervens is in general lines similar to those of Prionyx atratus (Lepeletier, 1845) as described by Evans (1958).

\section{ACKNOWLEDGEMENTS}

Thanks to Cláudia Santos for identifying the grasshopper and the Conselho Nacional de Desenvolvimento Científico e Tecnológico (CNPq) for the financial support (process 151153/ 2005-1).

\section{REFERENCES}

Amarante, S.T.P. 2002. A synonymic catalog of the neotropical Crabronidae and Sphecidae (Hymenoptera: Apoidea). Arquivos de Zoologia, São Paulo, 37 (1): 102-139.

Bondar, G. 1915. Vespas caçadoras de gafanhotos. Boletim Agrícola, São Paulo, 665: 442-444.

BOHART, R.M. \& A.S. MENKE. 1976. Sphecidae wasps of the world - a generic revision. Berkeley, University of California Press, $665 p$.

Evans, H.E. 1958. Studies on the nesting behaviour of the digger wasps of the tribe Sphecini. Part I. Genus Pryononyx Dahlbom. Annals of the Entomological Society of America, College Park, 51: 177-186

Evans, H.E.; A.W. Hook \& R.W. Matthews. 1982. Nesting behaviour of Australian wasps of the genus Sphex (Hymenoptera, Sphecidae). Journal of Natural History, London, 16 (2): 219-225.

Genise, J.F. 1980. Comportamiento de nidificacion de Prionyx bifoveolatus (Tasch.) (Hymenoptera: Sphecidae). Physis (Seccion C, los Continentes y los Organismos Terrestres), Buenos Aires, 39 (96): 51-54.

GenISE, J.F. 1981. Influencia de factores meteorologicos en la actividad de Prionyx bifoveolatus (Tasch.) (Hymenoptera: Sphecidae). Physis, (Seccion C, los Continentes y los Organismos Terrestres), Buenos Aires, 39 (97): 19-24.

Grissell, E.E. 1981. Nesting behavior of Prionyx 'thomae' (Fabricius) (Hymenoptera: Sphecidae). Journal of the Kansas Entomological Society, Manhattan, 54 (1): 16-21.

Hartman, C.G. 1905. Observations on the habitats of some solitary wasps of Texas. Bulletin of the University of Texas, Austin, 65: 1-72.

JANvier, H. 1928. Recherches biologiques sur les prédateurs du Chili. Annales des Sciences Naturelles Zoologie, Paris, 16 (10): 209-356.

RaU, P. \& N. Rau. 1918. Wasp studies afield. New York, Dover Publications, 372p.

Steiner, A.L. 1981. Anti-predator strategies. II. Grasshoppers (Orthoptera, Acrididae) attacked by Prionyx parkeri and some Tachysphex wasps (Hymenoptera, Sphecinae and Larrinae): a descriptive study. Psyche, Massachusetts, 88 (1-2): 1-24.

STEINER, A.L. 1982. Use of the proboscis for prey piercing and sucking by sphecid wasps of the genus Prionyx (Hymenoptera: Sphecidae), a case of convergent evolution. Pan-Pacific Entomologist, San Francisco, 58 (2): 129-134.

Willink, A. 1951. Las especies argentinas y chilenas de “ Chloriontini" (Hym., Sphecidae). Acta Zoologica Lilloana, Tucuman, 11: 53-225.

Received in 24.VI.2005; accepted in 27.III.2006. 